\title{
Mushroom corals (Scleractinia, Fungiidae) of Espiritu Santo (Vanuatu, West Pacific), with the description of a new species
}

Bert W. HOEKSEMA

Department of Marine Zoology, Netherlands Centre for Biodiversity Naturalis, P.O. Box 9517, 2300 RA Leiden (The Netherlands)

bert.hoeksema@ncbnaturalis.nl

KEY WORDS

Cnidaria,

Anthozoa,

Hexacorallia,

Scleractinia,

Fungiidae,

Vanuatu,

Espiritu Santo,

Coral Triangle,

new species.

MOTS CLÉS

Cnidaria, Anthozoa,

Hexacorallia,

Scleractinia,

Fungiidae,

Vanuatu,

Espiritu Santo,

Triangle du corail,

espece nouvelle.
Hoeksema B. W. 2012. - Mushroom corals (Scleractinia, Fungiidae) of Espiritu Santo (Vanuatu, West Pacific), with the description of a new species. Zoosystema 34 (2): 429-443. http://dx.doi.org/10.5252/z2012n2a14

\begin{abstract}
A total of 35 mushroom coral species (Scleractinia, Fungiidae) was recorded at the southeastern coast of Espiritu Santo, northern Vanuatu, during the SANTO 2006 expedition. One species, Sandalolitha boucheti n. sp., is described as new to science. It can be distinguished from its congeners by dense and thin septa, fine serrated septal dentations, evenly distributed stomata, and a light brown colour. The present species number is distinctly higher than previous records and suggests that northern Vanuatu, Espiritu Santo in particular, should be included in the so-called Coral Triangle, the Indo-West Pacific centre of maximum marine biodiversity, which would require an extension of this area in southeastward direction.
\end{abstract}

\section{RÉSUMÉ}

Coraux champignons (Scleractinia, Fungiidae) d'Espiritu Santo (Vanuatu, Pacific ouest), avec la description d'une novelle espèce.

Un total de 35 espèces de coraux champignons (Scleractinia, Fungiidae) a été rapporté de la côte sud-est d'Espiritu Santo, au nord du Vanuatu, pendant l'expédition SANTO 2006. Une de ces espèces, Sandalolitha boucheti n. sp., nouvelle pour la science, est décrite ici. Elle se distingue de ses congénères par des septa nombreux et fins, des indentations septales finement serrulées, des stomates distribués régulièrement et une coloration brun clair. Le nombre d'espèces est bien plus grand que ce qui a été précedemment rapporté, ce qui suggère que le nord du Vanuatu, et plus particulièrement Espiritu Santo, devrait être inclus dans ce que l'on appelle le Triangle du corail - le centre du bassin Indo-Pacifique qui possède une biodiversité marine maximale -, et donc que cette zone doit être agrandie en direction du sud-est. 


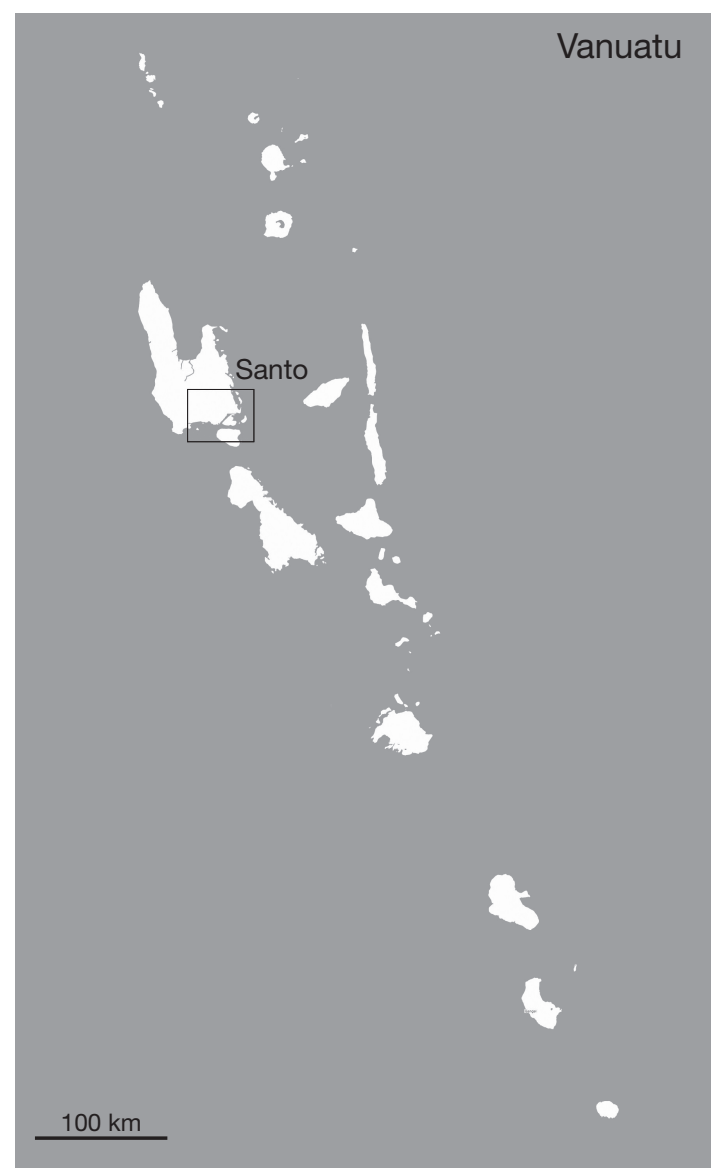

FIG. 1. - Map of Vanuatu indicating the position of Espiritu Santo and the sampled area.

\section{INTRODUCTION}

Mushroom corals (Scleractinia Bourne, 1900, Fungiidae Dana, 1846) are stony reef corals. Because of their striking appearance, they are well known from coral reefs across the tropical Indo-Pacific (Hoeksema 1989). Most species have a free-living adult stage in their life cycle after becoming detached from a stalk (Hoeksema \& Yeemin 2011). A few others have lost this ability and remain attached to a hard substrate (Hoeksema 1989, 2009). They are generally common reefdwellers and in various reef areas free-living species have been observed to form dense aggregations of mixed or single species, depending on their ability of asexual reproduction through budding or fragmentation (Hoeksema 1991, 2004, 2012; Hoeksema \& Koh 2009; Hoeksema \& Gittenberger 2010; Hoeksema \& Matthews 2011; Hoeksema \& Waheed 2011).

Owing to their mobility, free-living mushroom corals inhabit various kinds of substrates. They can be found in a range of reef environments, from shallow reef flats to deep sandy reef bases and from reefs near river mouths to offshore oceanic reefs (e.g., Hoeksema \& Moka 1989; Cleary et al. 2005; Becking et al. 2006; Hoeksema 2012). Because they are relatively common reef-dwellers and easy to spot, mushroom corals constitute a suitable model group as a proxy for assessing species richness in biodiversity surveys. At present 50 Fungiidae are recognised, which form a monophyletic taxon (Gittenberger et al. 2011). In biodiversity studies, they have additional value as host corals of many associated species, such as molluscs, crabs, shrimps and fish (Bos 2011; Hoeksema \& Fransen 2011; Hoeksema \& Gittenberger 2011; Hoeksema et al. 2012).

The present study deals with the mushroom coral fauna of Vanuatu, in particular the southeastern part of Espiritu Santo, which was surveyed during the SANTO 2006 expedition (Bouchet et al. 2011). Previous knowledge on the mushroom coral fauna of Vanuatu, West Pacific, was based on a few old studies, including a taxonomic revision of the Fungiidae (Hoeksema 1989) and reports on the scleractinian corals of Vanuatu (Veron 1990a, b). This resulted in a preliminary species number of 20 (Table 1) out of a total of 50 (Gittenberger et al. 2011). The fieldwork reported in the present study specifically dealt with mushroom corals of Santo in order to obtain a better overview of which fungiid species are present or absent, which resulted in a new total of 35 mushroom coral species. This will allow a comparison with results from areas in the so-called Coral Triangle, the centre of maximum marine species diversity (Hoeksema 2007; Veron et al. 2009, 2011) with a total of 46 known species (Hoeksema unpubl.), and from New Caledonia (see Pichon 2006), a neighbouring area that so far has not been considered part of this marine biodiversity centre (Veron et al. 2011). 
TABLE 1. - Mushroom coral species and their occurrence recorded from 25 sites during the SANTO 2006 expedition. One species (*) was observed at another SANTO 2006 site. Earlier records from Vanuatu are referenced as well as some other West Pacific areas, New Caledonia and Madang (Bismarck Sea, Papua New Guinea): [1], Hoeksema (1989); [2], Veron (1990a, b); [3], Laboute \& Richer de Forges (2004); [4], Pichon (2006); [5], Hoeksema (1993a). Notes: (1), As Fungia (Ctenactis) simplex (Gardiner, 1905); (2), as Cycloseris patelliformis (Boschma, 1923); (3), maybe partly as Lithophyllon undulatum Rehberg, 1892; (4), also as Fungia (Danafungia) valida Verrill, 1864, and F. (D.) klunzingeri Döderlein, 1901; (5), as Fungia (D.) danai Milne Edwards \& Haime, 1851; (6), possibly as Fungia (Verillofungia) sp.; (7), as Podabacia sp.; (8), as Ctenactis echinata; (9), as Cycloseris patelliformis and Diaseris distorta; (10), as Cycloseris cyclolites; (11), record based on re-examined collection material and photographs.

\begin{tabular}{|c|c|c|c|c|}
\hline Species & $\begin{array}{l}\text { Number of } \\
\text { dive sites, } \\
\text { SANTO } 2006\end{array}$ & $\begin{array}{l}\text { Earlier } \\
\text { records } \\
\text { Vanuatu }\end{array}$ & $\begin{array}{c}\text { New } \\
\text { Caledonia } \\
\text { Sea }\end{array}$ & $\begin{array}{c}\text { Madang } \\
\text { Bismarck }\end{array}$ \\
\hline Cantharellus jebbi Hoeksema, 1993 & 17 & - & - & [5] \\
\hline Cantharellus noumeae Hoeksema \& Best, 1984 & - & - & [4] & - \\
\hline Ctenactis albitentaculata Hoeksema, 1989 & 6 & - & {$[3,4]$} & [5] \\
\hline Ctenactis echinata (Pallas, 1766) & 18 & [2] & [4] & [5] \\
\hline Ctenactis crassa (Dana, 1846) & 17 & [2] ${ }^{1}$ & {$\left[3^{8}, 4\right]$} & [5] \\
\hline Cycloseris costulata (Ortmann, 1889) & 16 & - & [4] & [5] \\
\hline Cycloseris curvata (Hoeksema, 1989) & - & - & - & {$[5]^{11}$} \\
\hline Cycloseris cyclolites (Lamarck, 1815) & $1^{*}$ & _ & {$[3,4]$} & [5] \\
\hline Cycloseris distorta (Michelin, 1842) & - & - & [4] & {$[5]^{11}$} \\
\hline Cycloseris fragilis (Alcock, 1893) & 4 & {$[2]^{2}$} & {$\left[3^{9}, 4\right]$} & {$[5]$} \\
\hline Cycloseris hexagonalis (Milne Edwards \& Haime, 1848) & 1 & - & - & [5] \\
\hline Cycloseris mokai (Hoeksema, 1989) & 9 & {$[2]^{3}$} & [4] & [5] \\
\hline Cycloseris sinensis Milne Edwards \& Haime, 1851 & 7 & - & {$[3,4]$} & [5] \\
\hline Cycloseris somervillei (Gardiner, 1909) & 2 & - & {$\left[3^{10}, 4\right]$} & [5] \\
\hline Cycloseris tenuis (Dana, 1846) & 1 & - & - & [5] \\
\hline Cycloseris vaughani (Boschma, 1923) & 3 & - & [4] & [5] \\
\hline Cycloseris sp. & 5 & _- & - & {$[5]^{11}$} \\
\hline Danafungia horrida (Dana, 1846) & 15 & {$[1,2]^{4}$} & [4] & [5] \\
\hline Danafungia scruposa (Klunzinger, 1879) & 13 & {$[2]^{5}$} & [4] & [5] \\
\hline Fungia fungites (Linnaeus, 1758) & 24 & {$[1,2]$} & {$[3,4]$} & [5] \\
\hline Halomitra clavator Hoeksema, 1989 & - & - & - & [5] \\
\hline Halomitra pileus (Linnaeus, 1758) & 1 & - & [4] & [5] \\
\hline Heliofungia actiniformis (Quoy \& Gaimard, 1833) & 5 & [1] & {$[3,4]$} & [5] \\
\hline Heliofungia fralinae (Nemenzo, 1955) & - & - & - & {$[5]^{11}$} \\
\hline Herpolitha limax (Esper, 1797) & 23 & {$[1,2]$} & {$[3,4]$} & [5] \\
\hline Lithophyllon concinna (Verrill, 1864) & 18 & [2] & [4] & [5] \\
\hline Lithophyllon repanda (Dana, 1846) & 22 & [2] & [4] & [5] \\
\hline Lithophyllon scabra (Döderlein, 1901) & - & - & [4] & - \\
\hline Lithophyllon spinifer (Claereboudt \& Hoeksema, 1987) & 9 & $-{ }^{6}$ & {$[4]$} & [5] \\
\hline Lithophyllon undulatum Rehberg, 1893 & - & [2] & - & [5] \\
\hline Lobactis scutaria (Lamarck, 1801) & 12 & [2] & {$[3,4]$} & [5] \\
\hline Pleuractis granulosa (Klunzinger, 1879) & 19 & [2] & [4] & [5] \\
\hline Pleuractis gravis (Nemenzo, 1955) & 9 & - & [4] & [5] \\
\hline Pleuractis moluccensis (Van der Horst, 1919) & 9 & - & [4] & [5] \\
\hline Pleuractis paumotensis (Stutchbury, 1833) & 23 & [2] & [4] & [5] \\
\hline Podabacia crustacea (Pallas, 1766) & 3 & [2] & {$[3,4]$} & [5] \\
\hline Podabacia motuporensis Veron, 1990 & 1 & {$[2]^{7}$} & - & [5] \\
\hline Polyphyllia novaehiberniae (Lesson, 1831) & 16 & {$[1,2]$} & [4] & [5] \\
\hline Polyphyllia talpina (Lamarck, 1801) & 15 & - & {$[3,4]$} & [5] \\
\hline Sandalolitha boucheti n. sp. & 13 & - & - & - \\
\hline Sandalolitha dentata Quelch, 1884 & - & - & - & [5] \\
\hline Sandalolitha robusta (Quelch, 1886) & 22 & [2] & {$[3,4]$} & [5] \\
\hline Zoopilus echinatus Dana, 1846 & 1 & [2] & - & [5] \\
\hline Total of species & 35 & 20 & 31 & 40 \\
\hline
\end{tabular}




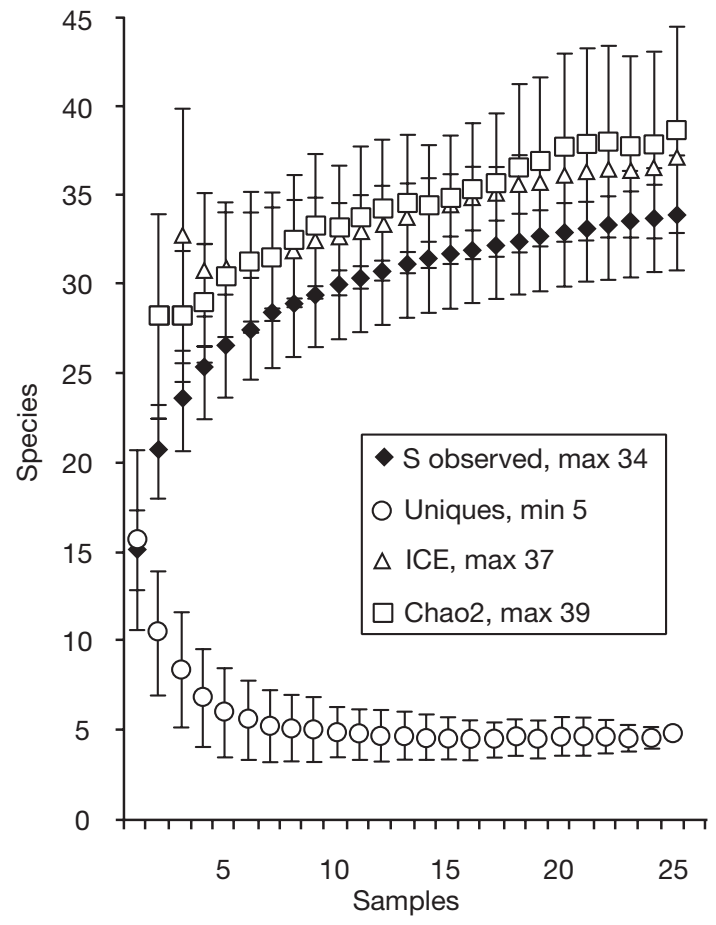

FIG. 2. - Species richness analysis of the mushroom coral fauna of Espiritu Santo with the help of EstimateS 8.2.0. (Colwell 2009): Chao2 is an incidence-based species richness estimator; ICE is an Incidence-based Coverage Estimator; S observed represents the recorded species numbers; and Unique values indicate species only encountered once.

\section{MATERIAL AND METHODS}

Mushroom coral species were recorded during the SANTO 2006 expedition in the vicinity of the base camp at Luganville in the southeastern coastal area of Espiritu Santo (Fig. 1; for detailed map, see Bouchet et al. 2009). The corals were surveyed during 25 dives (0-35 $\mathrm{m}$ deep) in a time span of 15 days (September 2006). Identifications were based on a taxonomic revision of the Fungiidae (Hoeksema 1989) and subsequent descriptions of species mentioned by Hoeksema (1993), all of which are listed with a phylogenetically adapted classification by Gittenberger et al. (2011). Two coral species that belong to the Fungiidae according to molecular studies, but which are still classified with the Siderastreidae (Benzoni et al. 2007), have not been included in the present study, i.e. Cycloseris explanulata (Van der Horst, 1922) and C. wellsi (Veron and Pichon, 1980). Formally they did not yet belong to the Fungiidae during the expedition and therefore they were not recorded. Meanwhile their formal status as Fungiidae will be corrected (Benzoni et al. in press). Material has been deposited in the coral collection of the Netherlands Centre of Biodiversity Naturalis with catalogue numbers RMNH Coel.
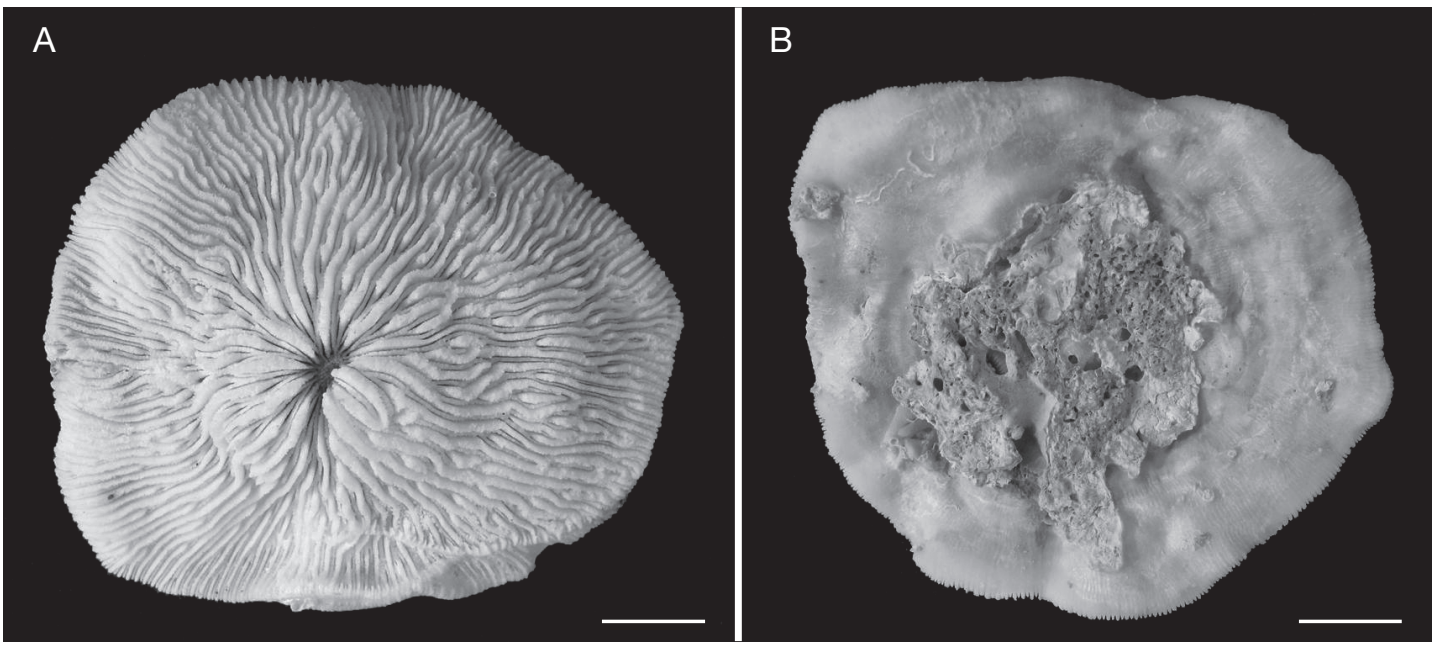

FIG. 3. - Cantharellus jebbi Hoeksema, 1993 (RMNH Coel. 40129) from Vanuatu, Espiritu Santo, SE coast, NE Aoré Island, N Aïmbuéi Bay: A, upper surface; B, lower surface showing attachment area. Scale bars: $1 \mathrm{~cm}$. 
The mushroom coral fauna was analysed for species richness with the help of EstimateS 8.2.0 (Colwell 2009). The species richness estimators resulting from the analysis are presented as species accumulation curves in which the sample order has been randomised and the values have been averaged (means and standard deviations are given per sample number). They are extrapolated to indicate total species richness (ob- served and expected). A reliable measure for species richness is obtained when the curves of the species richness estimators become asymptotic (the mean values flatten out), minimal standard deviations are obtained (approaching or reaching 0 ), and observed and expected values become equal. The used species richness indicators based on incidence (presence/absence) data are: 1) Chao 2 (an incidence-based species
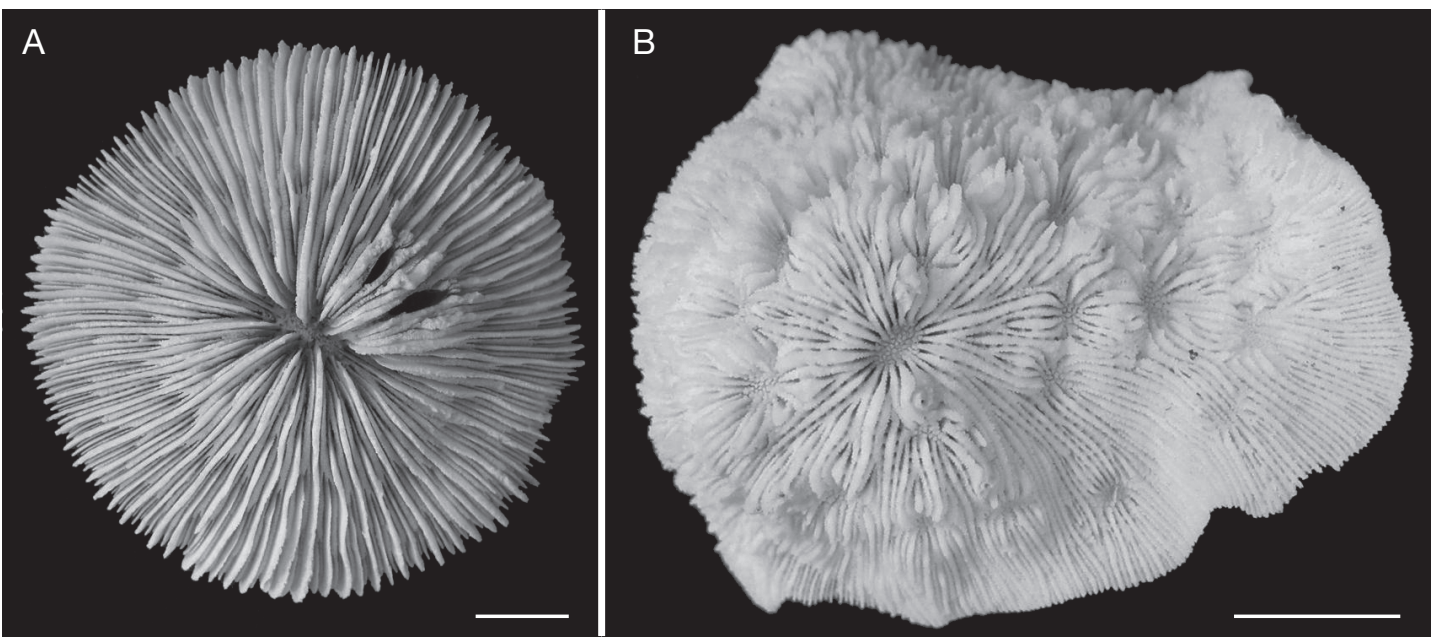

FIG. 4. - Mushroom corals from Vanuatu, Espiritu Santo, SE coast, Coolridge wreck. A, Cycloseris costulata (Ortmann, 1889) (RMNH Coel. 40134) with coral gall crab pits; B, Cycloseris mokai (Hoeksema, 1989) (RMNH Coel. 40130). Scale bars: $1 \mathrm{~cm}$.
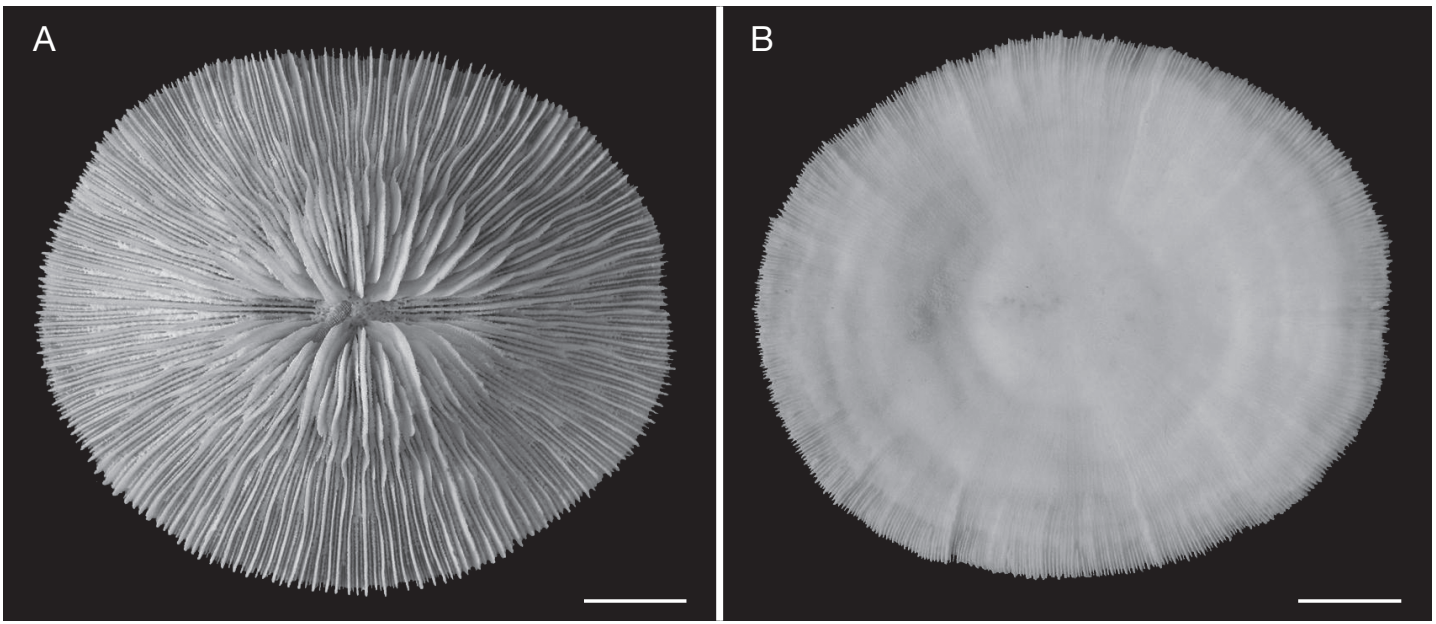

FIG. 5. - Cycloseris somervillei (Gardiner, 1909) (RMNH Coel. 40133) from Vanuatu, Espiritu Santo, SE coast, S Aoré Island, Bruat channel, N Perumamasa Island: A, upper surface; B, lower surface. Scale bars: $1 \mathrm{~cm}$. 

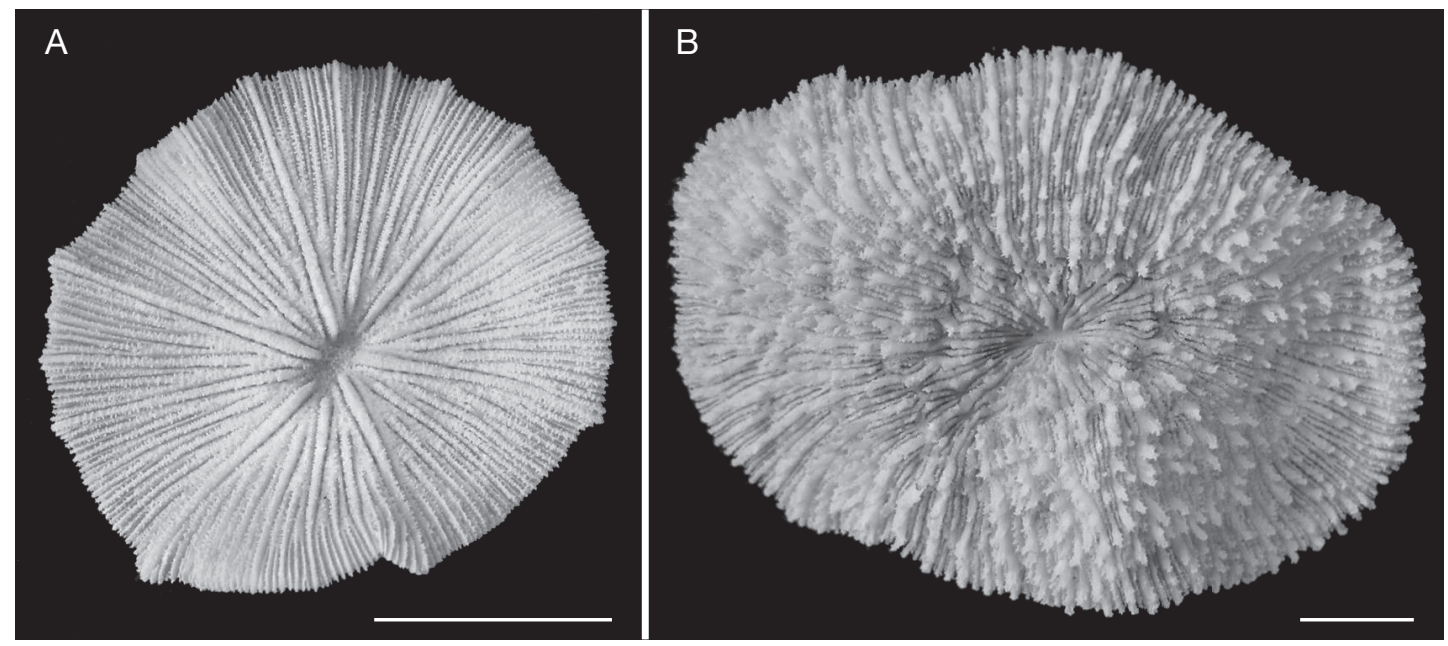

FIG. 6. - Mushroom corals from Vanuatu, Espiritu Santo, SE coast: A, Cycloseris hexagonalis (Milne Edwards \& Haime, 1848) (RMNH Coel. 40132) S Aoré Island, Bruat Channel; B, Zoopilus echinatus Dana, 1846 (RMNH Coel. 40136) N Tutuba Island. Scale bars: 1 cm.

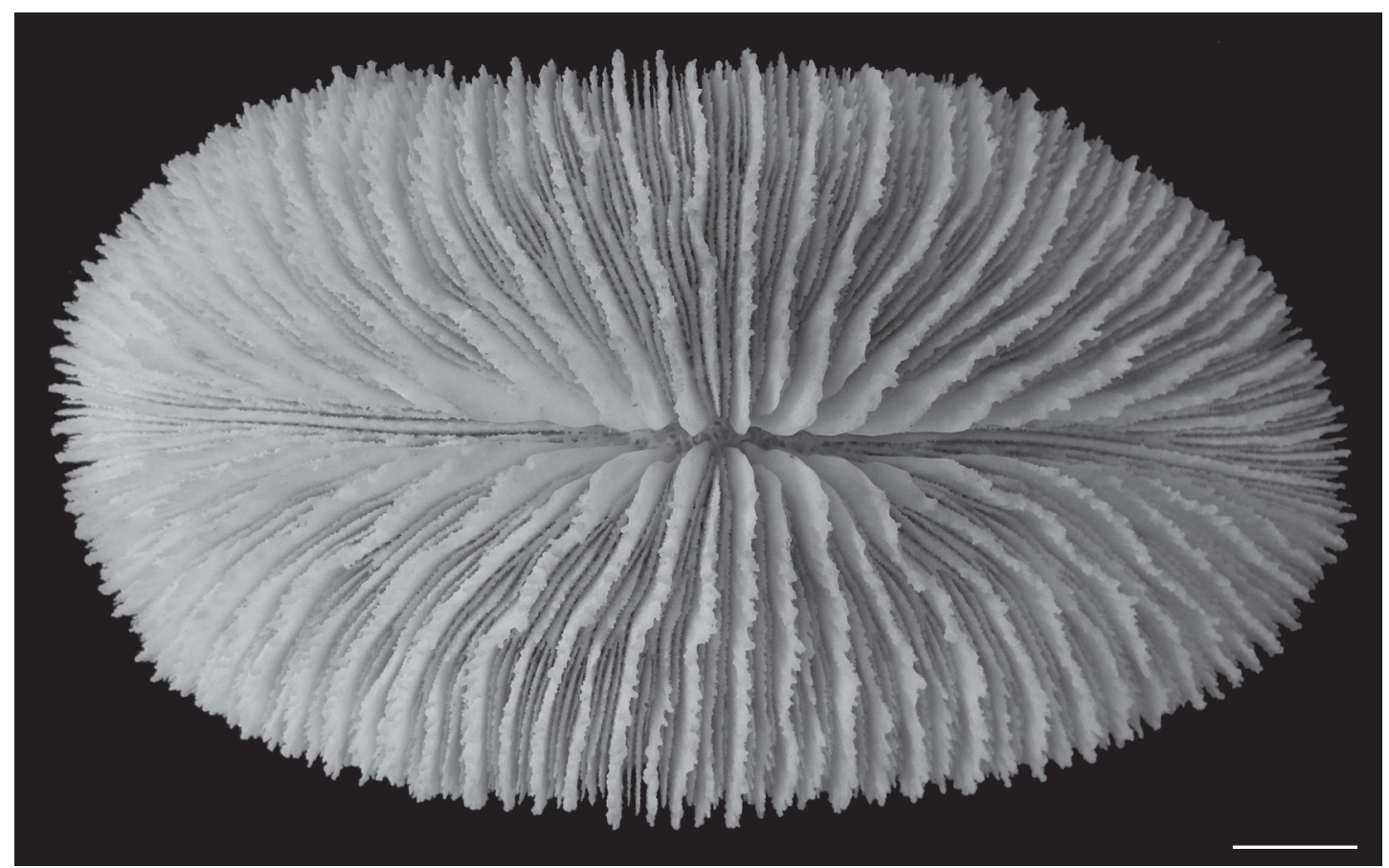

FIG. 7. - Ctenactis albitentaculata Hoeksema, 1989 (RMNH Coel. 40128) from Vanuatu, Espiritu Santo, SE coast, E Aoré Island, Alsari Bay, SE Bukora Point. Scale bar: $1 \mathrm{~cm}$. 

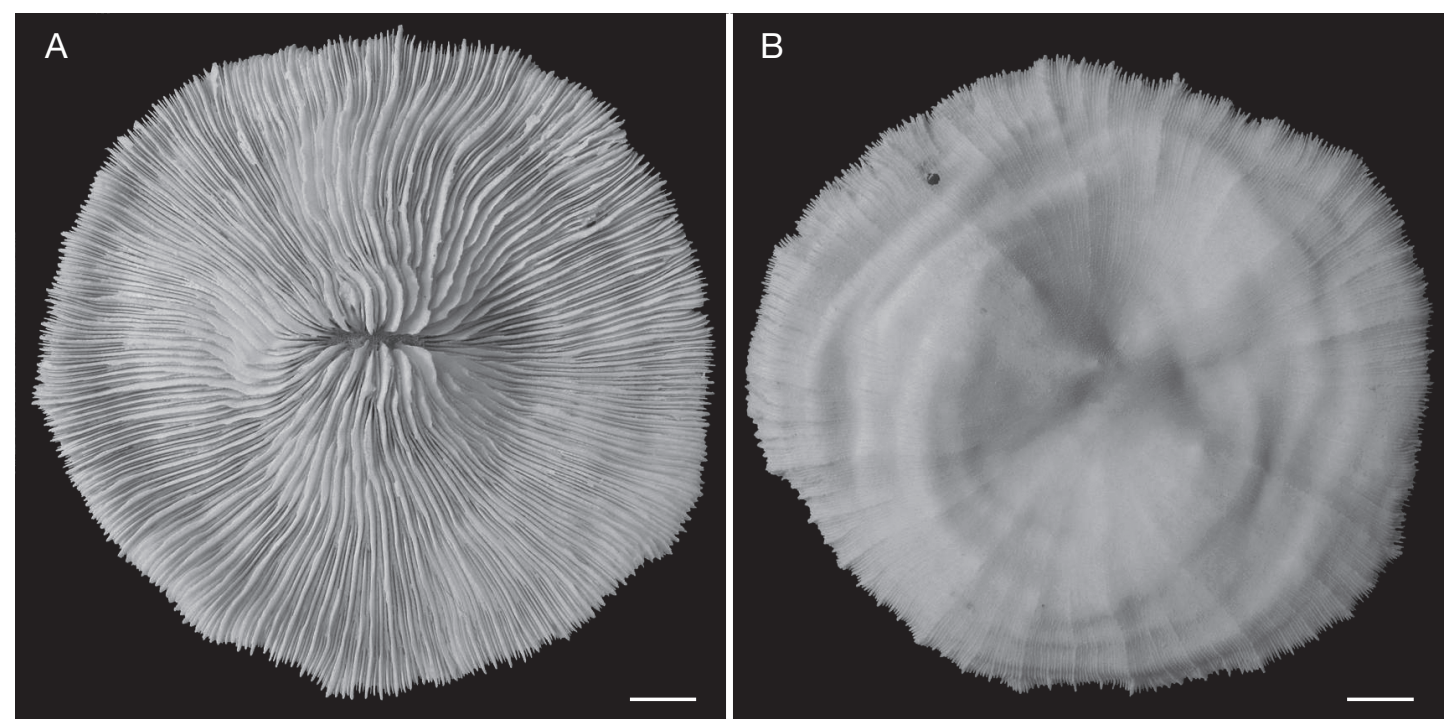

FIG. 8. - Lithophyllon spinifer (Claereboudt \& Hoeksema, 1987) (RMNH Coel. 40127) from Vanuatu, Espiritu Santo, SE coast, Coolridge wreck: A, upper surface; B, lower surface. Scale bars: $1 \mathrm{~cm}$.

richness estimator); 2) ICE (an incidence-based coverage estimator); 3) Sobs (the observed species numbers); and 4) Unique values (Colwell 2009).

\section{RESULTS}

At the 25 survey sites, 34 mushroom coral species were recorded. A specimen of an additional species, Cycloseris cyclolites, was found at another expedition locality (40 m deep) by Eric Folcher (Table 1). The total number of 35 species recorded for Santo appears, however, to be an underestimation according to the species richness analysis with the help of EstimateS 8.2.0 (Fig. 2). The observed number of species (Sobs $=34)$ and both species richness estimators (Chao2 $=39$ and ICE = 37) have not yet reached an asymptote value, while the number of unique species (species represented by a single record) is 5, indicating that it is likely that some other species may have been overlooked.

Sixteen species represent new records for Vanuatu. Some of these are little known, like Cantarellus jebbi (Fig. 3). This encrusting species can be confused with Cycloseris mokai, also representing a new record, which has finer septa and a higher concentration of stomata (Fig. 4B). For both of these species, and for the newly recorded $C$. hexagonalis (Fig. 6A) and Sandalolitha boucheti n. sp. (Figs 11-14), Vanuatu is the southeasternmost known locality to date. Other new records for Vanuatu concern Cycloseris costulata (Fig. 4A), C. cyclolites, C. sinensis, C. somervillei (Fig. 5), C. tenuis, C. vaughani, Cycloseris sp., Ctenactis albitentaculata (Fig. 7), Halomitra pileus, Lithophyllon spinifer (Fig. 8), Pleuractis gravis (Fig 9) and P. moluccensis (Fig. 10). Zoopilus echinatus, which also has its southeasternmost distribution limit at Espiritu Santo, was encountered as large free-living corals and as small juveniles with fresh detachment scars (Fig. 6B).

Descriptions of 33 species occurring in Vanuatu are given by Hoeksema (1989, 1993a). Two species are new to science, one of which, Sandalolitha boucheti n. sp., is described here. Its characters are decribed in a similar way as those of the two other Sandalolitha species, S. robusta and $S$. dentata, in order to facilitate comparisons (see Hoeksema 1989). The other one, a relatively widespread, small, and free-living Cycloseris species, will be described in a subsequent paper. 

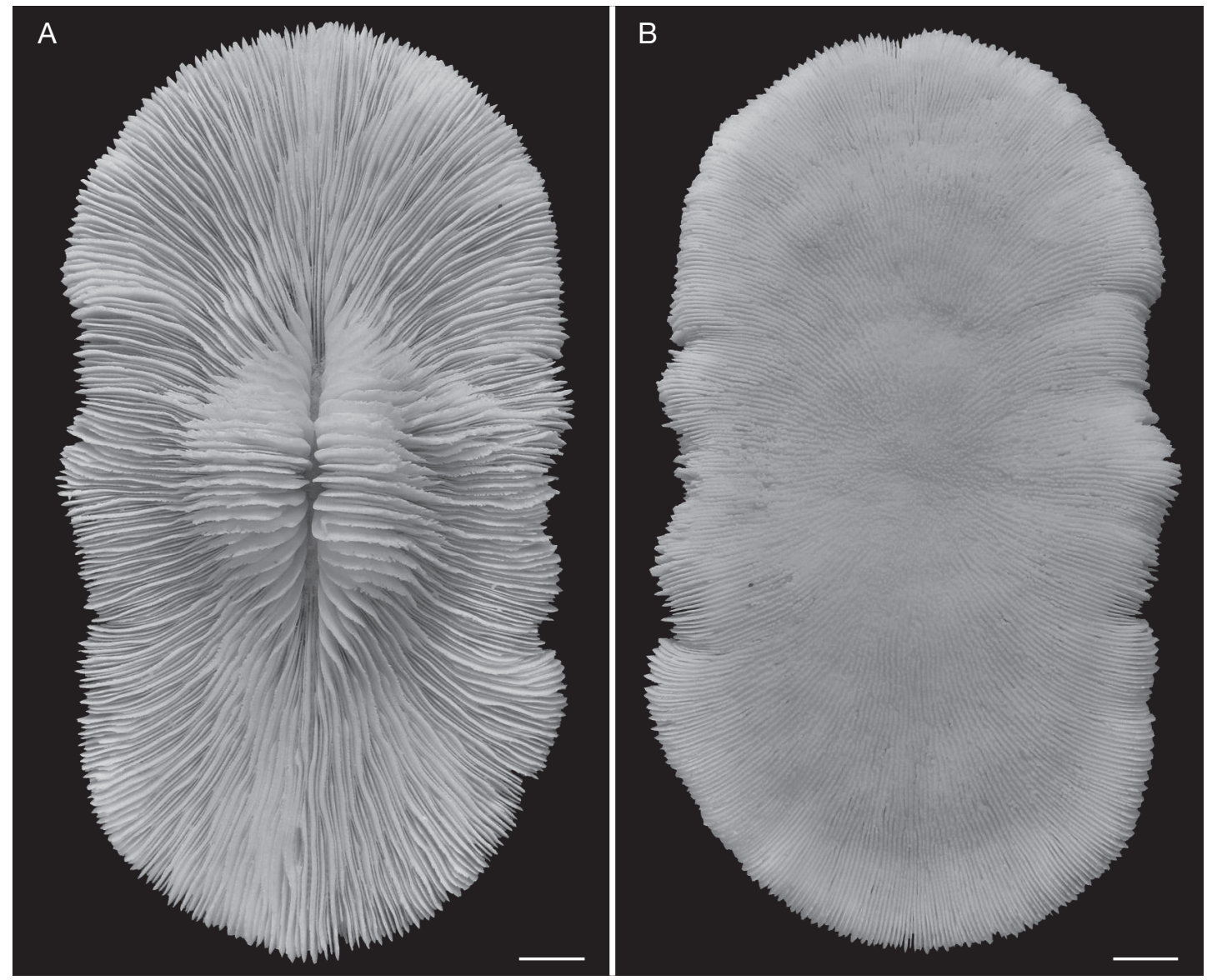

FIG. 9. - Pleuractis gravis (Nemenzo, 1955) (RMNH Coel. 40135) from Vanuatu, Espiritu Santo, SE coast, NW Aoré Island, Segon Channel: A, upper surface; B, lower surface. Scale bars: $1 \mathrm{~cm}$.

\section{SYSTEMATICS}

Order SCLERACTINIA Bourne, 1900

Family FUnGIIDAE Dana, 1846

Genus Sandalolitha Quelch, 1884

\section{Sandalolitha boucheti $\mathrm{n}$. sp.}

TYPE MATERIAL. - Holotype: SANTO 2006, stn FR8, Vanuatu, Espiritu Santo, SE coast, E Aoré Island, S Aïmbuéi Bay, $15^{\circ} 19^{\prime} 50,8^{\prime \prime}$ S, $167^{\circ} 07^{\prime} 18,5^{\prime \prime}$, depth 4 m., 14.IX.2006, B. W. Hoeksema (RMNH Coel. 40125; Fig. 11).

Paratype: SANTO 2006, stn FR20, Vanuatu, Espiritu Santo, SE coast, E Aoré Island, S Aïmbuéi Bay, $15^{\circ} 19^{\prime} 53,4^{\prime \prime} S, 167^{\circ} 07^{\prime} 26,5^{\prime}$ E, depth 8 m, 19.IX.2006, B. W. Hoeksema (RMNH Coel. 40126; Fig. 12).

OTHER MATERIAL. - Malaysia, eastern Sabah, Semporna area, Ligitan Reef 1, South, Yoshi Point, $4^{\circ} 14^{\prime} 05.8^{\prime \prime} \mathrm{N}$, $118^{\circ} 33^{\prime 2} 26.7^{\prime}$ E, depth 15 m, 1.XII.2010, B. W. Hoeksema, (RMNH Coel. 39964; Figs 13; 14).

Type LOCALITY. - Vanuatu, Espiritu Santo.

Geographical distribution. - Sandalolitha boucheti n. sp. is so far only known from Vanuatu (West Pacific) and northeastern Borneo (Sulawesi Sea).

Etymology. - Named after Prof. Philippe Bouchet, leader of the marine component of the SANTO 2006 expedition. 

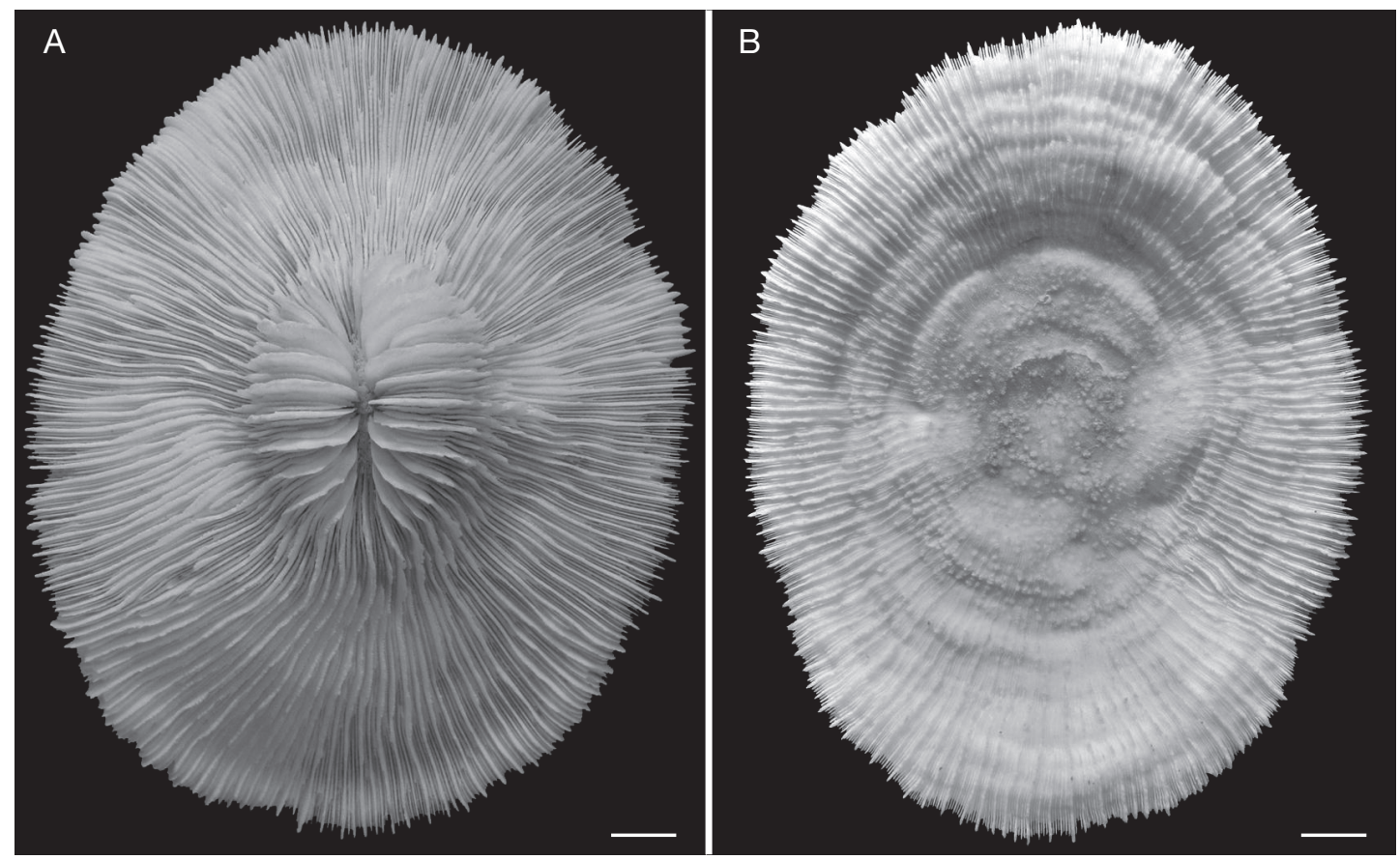

FIG. 10. - Pleuractis moluccensis (Van der Horst, 1919) (RMNH Coel. 40131) Vanuatu, Espiritu Santo, SE coast, E Aoré Island, S Aïmbuéi Bay: A, upper surface; B, lower surface. Scale bars: $1 \mathrm{~cm}$.

DIAGNOSIS. - Corals relatively smaller than congeners with septa that are finer densely packed and nearly of similar height, and with fine dentations (Table 2).

\section{DESCRIPTION}

Adult animals free-living. Polyps polystomatous by circumstomadaeal budding over the whole upper coral surface. Outline of corals varying from irregularly circular to oval. Corals varying from highly arched to slightly cup-shaped with a concave upper surface; length range: $8.0-13.5 \mathrm{~cm}$. Septa densely packed and straight, except around stomata, where they bend. Lower order septa thicker and more protruding than those of higher orders. Septa in small corals and higher order septa in larger corals fenestrate. Tentacular lobes absent. Septal margins finely ornamented with irregular serrate dentations, varying from 15 to 30 per $\mathrm{cm}$ (Fig. 11B). Septal sides covered by unevenly distributed coarse granulations. Compound synapticulae connecting the septa laterally not easily distinguishable because of the tight septal arrangement.
Stomata more or less evenly distributed over the coral surface. Columellae poorly developed, consisting of rudimentary trabeculae. Corallum wall perforated, covered by granulations and without fragmentation clefts. Large detachment scar (diameter 1.0-2.8 cm) distinct (Fig. 13C). Costae unequal in thickness and height, straight and distinct near the corallum margin, but less distinct near the centre; coarsely ornamented with echinous spines, varying from 15 to 30 per $\mathrm{cm}$ (Fig. 11C). Living animal light brown (Fig. 14). Small tentacles colourless and translucent.

\section{REMARKS}

Morphologically S. boucheti n. sp. shares some characters with either one of the other two Sandalolitha species, $S$. robusta and $S$. dentata (Table 2 ). With regard to stomata distribution, it resembles $S$. robusta by showing more or less evenly distributed stomata over the upper surface, while $S$. dentata has most stomata concentrated at the centre. With $S$. dentata it shares serrate septal dentations, while those of $S$. robusta are more lobate. 

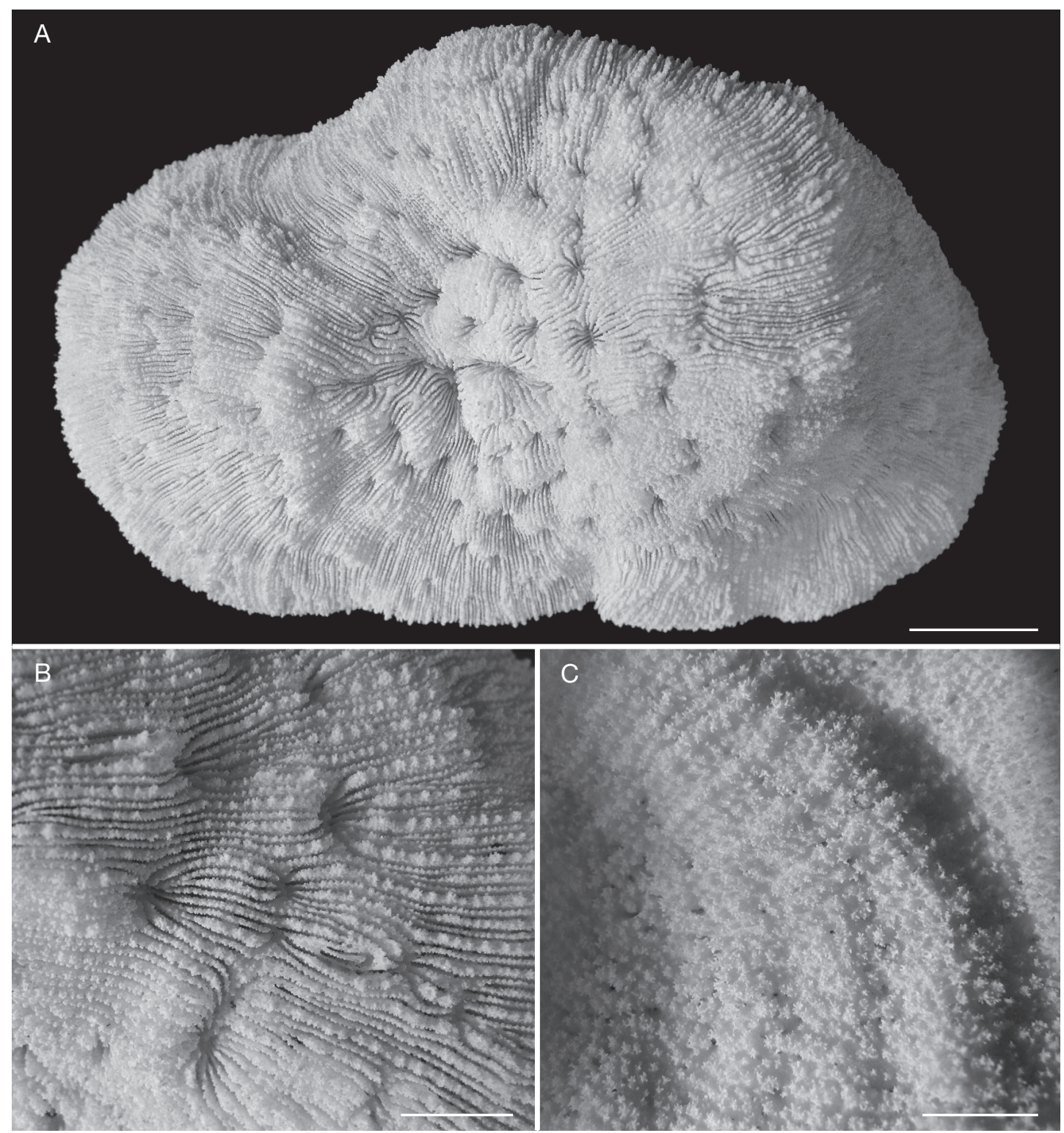

FIG. 11. - Holotype of Sandalolitha boucheti n. sp. (RMNH Coel. 40125) from Vanuatu, Espiritu Santo, SE coast, E Aoré Island, S Aïmbuéi Bay, depth $4 \mathrm{~m}$ : A, upper surface; B, details of septa; $\mathbf{C}$, details of costae. Scale bars: A, $1 \mathrm{~cm} ; \mathrm{B}, \mathrm{C}, 0.5 \mathrm{~cm}$.

Both type specimens show an oval shape, which is also common in $S$. dentata. However, compared to both other Sandalolitha species, it has finer septal and costal ornamentations and thinner septa and costae, which appear to be more densely arranged than in the other two species. S. boucheti n. sp. also differs from the other two species by being light brown in colour and from $S$. dentata in particular by lacking patches of green (see Hoeksema \& Van Ofwegen 2004). S. dentata was not recorded at Vanuatu (Table 1). 

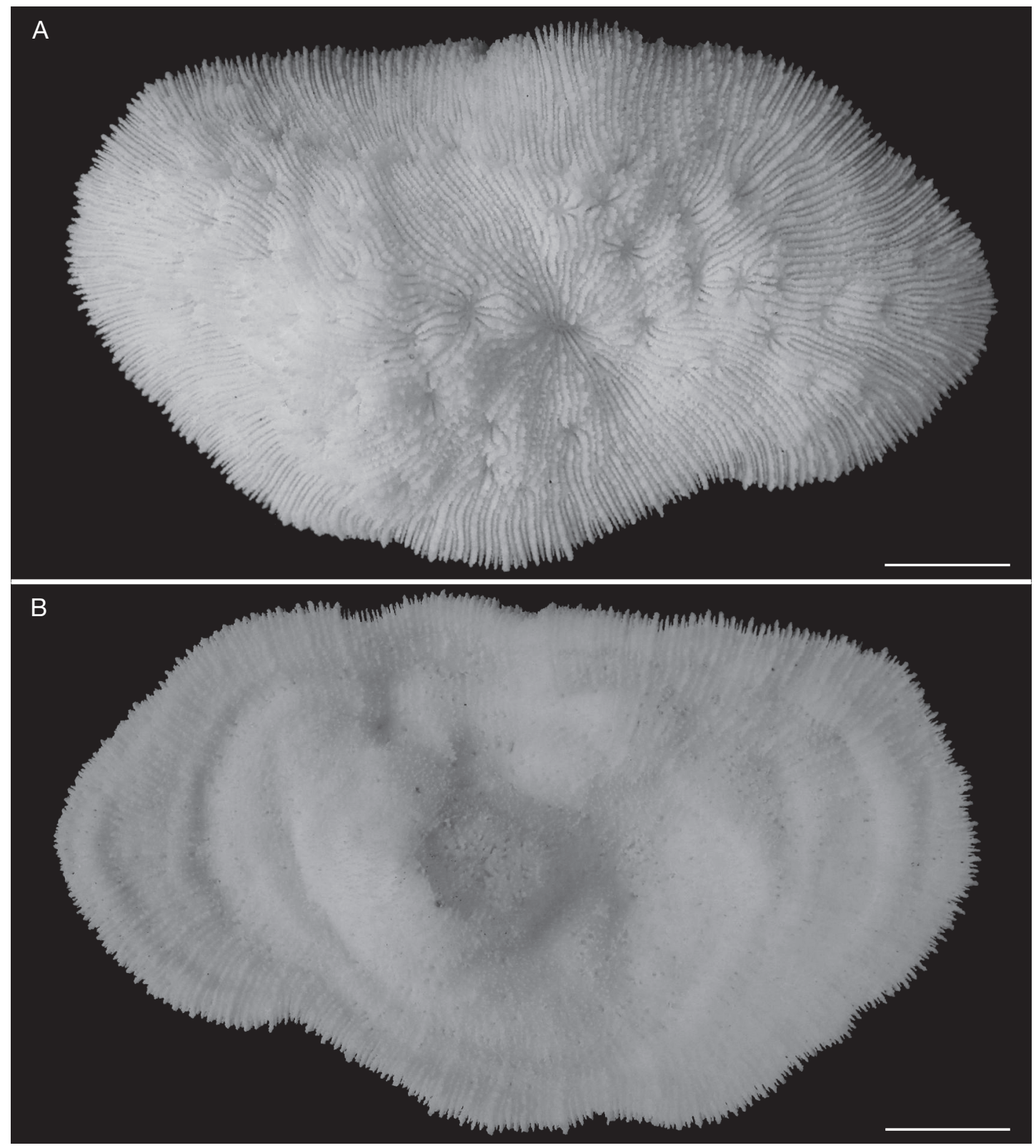

FIG. 12. - Paratype of Sandalolitha boucheti n. sp. (RMNH Coel. 40126) from Vanuatu, Espiritu Santo, SE coast, E Aoré Island, S Aïmbuéi Bay: A, upper surface; B, lower surface showing detachment scar. Scale bars: $1 \mathrm{~cm}$.

\section{DISCUSSION}

Although 35 mushroom coral species were recorded during the SANTO 2006 expedition (plus one extra observed by Veron [1990a, b], resulting in a total of 36), it is possible that some other species were overlooked as indicated by the species richness analysis (Fig. 2). In earlier reports (Veron 1990a, b), 

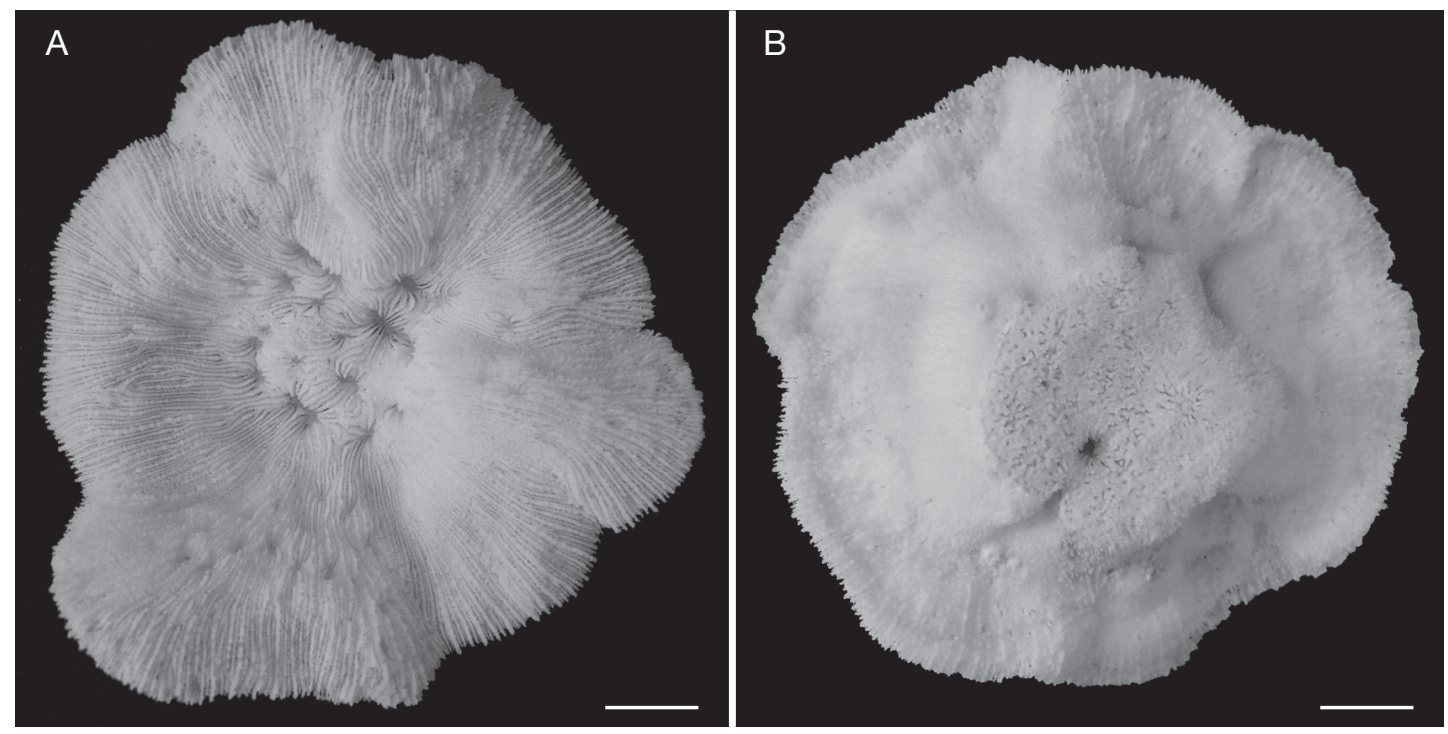

FIG. 13. - Specimen of Sandalolitha boucheti n. sp. (RMNH Coel. 39964) from Malaysia, eastern Sabah: A, upper surface; B, lower surface with large detachment scar. Scale bars: $1 \mathrm{~cm}$.

TABLE 2. - Characters of three Sandalolitha species (compare Hoeksema 1989).

\begin{tabular}{lccc}
\hline Character & $\begin{array}{c}\text { S. dentata } \\
\text { Quelch, 1884 }\end{array}$ & $\begin{array}{c}\text { S. robusta } \\
\text { (Quelch, 1886) }\end{array}$ & $\begin{array}{c}\text { S. boucheti } \\
\text { n. sp. }\end{array}$ \\
\hline $\begin{array}{l}\text { Distribution of stomata concentrated } \\
\text { at corallum centre or evenly distributed }\end{array}$ & concentrated & even & even \\
Septal dentations serrate or lobate & & & \\
Septa alternating or of nearly similar height & serrate & lobate & serrate \\
Septa and costae loosely packed or dense & loose & alternating & similar \\
Density of septal teeth (per $\mathrm{cm}^{2}$ ) & $8-25$ & loose & dense \\
\hline
\end{tabular}

23 species were mentioned from Vanuatu (Table 1), some of which are synonyms according to Hoeksema (1989). Another species, Heliofungia actiniformis, was recorded by Hoeksema (1989). Lithophyllon undulatum was listed by Veron (1990a, b) but it was not found during the SANTO 2006 expedition. This implies that only 20 fungiid species were observed during previous studies, all of which except one, L. undulatum, were also observed during the present survey. At least 14 of the presently listed species represent new records (Table 1). Two species that recently became recognised as Fungiidae, Cycloseris explanulata and C. wellsi (see Benzoni et al. 2007, in press) were not recorded during the present study and also not during earlier surveys of the scleractinian fauna of Vanuatu (Veron 1990a, b).

With regard to reef corals, Vanuatu is not considered part of the Coral Triangle (Veron et al. 2009, 2011), which may be based on the species lists presented by Veron (2009a, b). The ahermatypic (azooxanthellate) coral fauna of Vanuatu is also not considered rich enough to be part of the centre of diversity (Cairns 1999, 2007). However, the presently reported increase in the known number of mushroom coral species of Vanuatu, suggests that the number of all reef coral species $(n=296)$ at Vanuatu (Veron 1990a, b) should also be higher in proportion. The present mushroom coral data 
suggest that the centre of mushroom coral diversity (Hoeksema 2007) should have a southeastward extension, including Espiritu Santo and adjacent parts of Vanuatu (Hoeksema \& Gittenberger 2011). Compared to the Bismarck Sea with 40 species, Vanuatu is less rich in fungiid species (Hoeksema 1993a; Table 1) but in relation to New Caledonia with 31 species, which is located to the south, its species number is higher (Pichon 2006; Table 1). The number of 36 mushroom coral species in $\mathrm{Va}$ nuatu is higher than the 28-30 recorded in some Coral Triangle areas (Hoeksema 2007; Hoeksema \& Gittenberger 2011). Therefore Vanuatu's scleractinian fauna is expected to be rich enough to be considered part of centre of mushroom coral diversity and New Caledonia may also fit in with its present record of 31 fungiids. The southeastward extension of this centre may be explained by oceanic currents branching off from the South Equatorial Current (SEC), which have transported larvae of the coral species present here (see Hoeksema 2007).

Coral reef biota in the proximity of large cities may change within several decades of time as a result of human impact (Van der Meij et al. 2009, 2010; Hoeksema \& Koh 2009; Hoeksema et al. 2011). The human population of Vanuatu is not large and therefore it is unlikely that the mushroom coral fauna observed in 2006 has declined since the previous survey by Veron in 1988 (1990a, b). The only threat mentioned for mushroom corals is collecting for the curio trade, which is not mentioned to affect Vanuatu's coral fauna (Amos 2006).

The discovery of a new species during SANTO 2006 was not a unique happening. Since a recent taxonomic revision of the Fungiidae (Hoeksema 1989) various other mushroom coral species were reported as new to science (Veron 1990c, 2000; Hoeksema \& Dai 1991; Hoeksema 1993a, b, 2009; Ditlev 2003). Sandalolitha boucheti n. sp. is also not the only new marine species recorded as a result of SANTO 2006, since other new species were discovered from coral reefs and from anchialine, brackish, subtidal, and deep waters (Bamber 2009; Lane \& Rowe 2009; Mcpherson 2009, 2012; Neusser \& Schrödl 2009; Weiner et al. 2009; Boxshall \& Jaume 2012; McLean 2012; Séret \& Last 2012). All these new discoveries together confirm

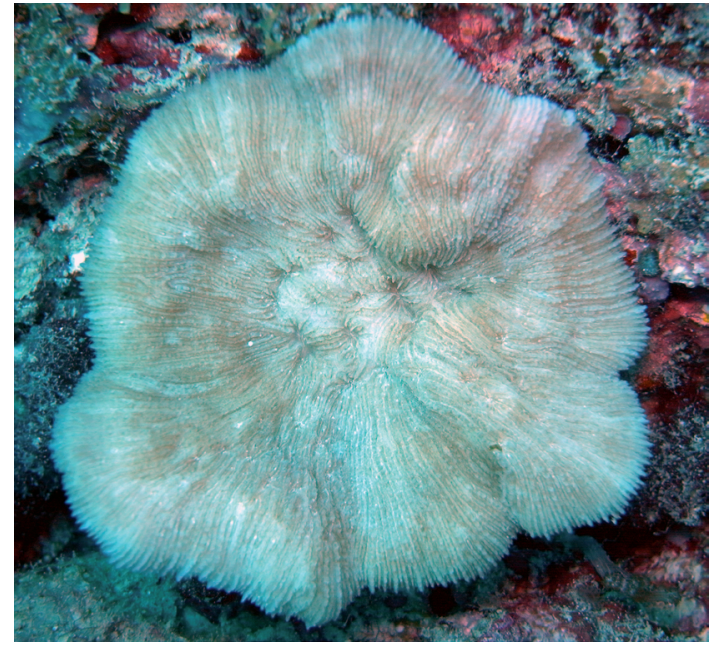

FIG. 14. - Live specimen of Sandalolitha boucheti n. sp. (RMNH Coel. 39964) from Malaysia, eastern Sabah, Semporna area, Ligitan Reef 1, South, Yoshi Point, depth $15 \mathrm{~m}$.

that expeditions to poorly investigated regions, such as Espiritu Santo, are indispensable for a good understanding of the marine realm and its species diversity patterns.

\section{Acknowledgements}

The SANTO 2006 expedition was organised by the Muséum national d'Histoire naturelle, Paris (MNHN), Pro-Natura International (PNI), and Institut de Recherche pour le Développement (IRD). It operated under a permit granted to Philippe Bouchet (MNHN) by the Environment Unit of the Government of Vanuatu. The Marine Biodiversity part of the expedition, a part of Census of Marine Life's CReefs programme, was specifically funded by grants from the Total Foundation and the Sloan Foundation. Philippe Bouchet (MNHN) allowed me to participate in SANTO 2006. Arjan Gittenberger (NCB Naturalis, Leiden) and Eric Folcher (IRD, Nouméa) acted as dive buddies and assisted in collecting. Zarinah Waheed assisted in making the photographs. I am grateful to three reviewers for their constructive remarks, which definitely improved the manuscript, F. Benzoni, A. Ohler and an anonymous referee. 


\section{REFERENCES}

Amos M. J. 2006. - Vanuatu fishery resource profiles. IWP-Pacific Technical Report 49: i-viii, 1-200.

BAmber R. N. 2009. - Two new species of shellinhabiting tanaidaceans (Crustacea, Peracarida, Tanaidacea, Pagurapseudidae, Pagurapseudinae) from the shallow sublittoral off Vanuatu. Zoosystema 31 (3) : 407-418. http://dx.doi.org/10.5252/z2009n3a1

Becking L. E., Cleary D. F. R., De Voogd N. J., Renema W., De Beer M., Van Soest R. W. M. \& HoEKSEMA B. W. 2006. - Beta-diversity of tropical marine assemblages in the Spermonde Archipelago, Indonesia. Marine Ecology 27: 76-88.

Benzoni F., Stefani F., Stolarski J., Pichon M., MitTa G., \& Galli P. 2007. - Debating phylogenetic relationships of the scleractinian Psammocora: molecular and morphological evidences. Contributions to Zoology 76: 35-54.

Benzoni F., Arrigoni R., Stefani F., Reijnen B. T., Montano S. \& Hoeksema B. W. (in press). - Phylogenetic position and taxonomy of Cycloseris explanulata and C. wellsi (Scleractinia: Fungiidae): lost mushroom corals find their way home. Contributions to Zoology.

Bos A. R. 2011. - Symbiotic fishes (Gobiidae and Labridae) of the mushroom coral Heliofungia actiniformis (Scleractinia; Fungiidae). Coral Reefs 31: 133.

Bouchet P., Le Guyader H. \& Pascal O. 2009. - The SANTO 2006 Global Biodiversity Survey: an attempt to reconcile the pace of taxonomy and conservation. Zoosystema 31 (3) : 401-406.

Bouchet P., Le Guyader H. \& Pascal O. (eds) 2011. The Natural History of Santo. Patrimoines Naturels 70. Muséum national d'Histoire naturelle, Paris; IRD, Marseille; Pro-Natura International, Paris, 572 p.

CAIRNS S. D. 1999. — Cnidaria Anthozoa: deep-water azooxanthellate Scleractinia from Vanuatu, and Wallis and Futuna Islands. Mémoires du Museum national d'Histoire naturelle 180: 31-167.

CAIRNS S. D. 2007. - Deep-water corals: an overview with special reference to diversity and distribution of deep-water scleractinian corals. Bulletin of Marine Science 80: 311-322.

Cleary D. F. R., Becking L. E., De Voogd N. J., Renema W., De Beer M., Van Soest R. W. M. \& HoEKSEMA B. W. 2005. - Variation in the diversity and composition of benthic taxa as a function of distance offshore, depth and exposure in the Spermonde Archipelago, Indonesia. Estuarine Coastal and Shelf Science 65: 557-570.

COLWELl R. K. 2009. - EstimateS: Statistical estimation of species richness and shared species from samples. Version 8.2.0. User's guide and application: http://viceroy.eeb. uconn.edu/estimates

Ditlev H. 2003. - New scleractinian corals (Cnidaria: Anthozoa) from Sabah, north Borneo. Description of one new genus and eight new species, with notes on their taxonomy and ecology. Zoologische Mededelingen Leiden 77: 193-219.

Gittenberger A., Reijnen B. T. \& Hoeksema B. W. 2011. - A molecularly based phylogeny reconstruction of mushroom corals (Scleractinia: Fungiidae) with taxonomic consequences and evolutionary implications for life history traits. Contributions to Zoology 80: 107-132.

HoeKsema B. W. 1989. - Taxonomy, phylogeny and biogeography of mushroom corals (Scleractinia: Fungiidae). Zoologische Verhandelingen, Leiden 254: 1-295.

HoeKsema B. W. 1991. - Control of bleaching in mushroom coral populations (Scleractinia: Fungiidae) in the Java Sea: stress tolerance and interference by life history strategy. Marine Ecology Progress Series 74: 225-237.

Hoeksema B. W. 1993a. - Mushroom corals (Scleractinia: Fungiidae) of Madang Lagoon, northern Papua New Guinea: an annotated checklist with the description of Cantharellus jebbi spec. nov. Zoologische Mededelingen, Leiden 67: 1-19.

Hoeksema B. W. 1993b. - Historical biogeography of Fungia (Pleuractis) spp. (Scleractinia: Fungiidae), including a new species from the Seychelles. Zoologische Mededelingen Leiden 67: 639-654.

HoeKsema B. W. 2004. - Impact of budding on free-living corals at East Kalimantan, Indonesia. Coral Reefs 23: 492.

Hoeksema B. W. 2007. - Delineation of the IndoMalayan Centre of Maximum Marine Biodiversity: the Coral Triangle, in RenEMA W. (ed.), Biogeography, Time and Place: Distributions, Barriers and Islands. Springer, Dordrecht: 117-178.

HoeKseMA B. W. 2009. - Attached mushroom corals (Scleractinia: Fungiidae) in sediment-stressed reef conditions at Singapore, including a new species and a new record. Raffles Bulletin of Zoology, suppl. 22: 81-90.

HoeKSEMA B.W. 2012. - Distribution patterns of mushroom corals (Scleractinia: Fungiidae) across the Spermonde Archipelago, South Sulawesi. Raffles Bulletin of Zoology 60: 183-212.

Hoeksema B. W. \& MoKa W. 1989. - Species assemblages and ecomorph variation of mushroom corals (Scleractinia: Fungiidae) related to reef habitats in the Flores Sea. Netherlands Journal of Sea Research 23:149160.

Hoeksema B. W. \& Dai C. F. 1991. - Scleractinia of Taiwan. II. Family Fungiidae (with the description of a new species). Bulletin Zoological Institute, Academia Sinica, Taipei 30: 201-226.

Hoeksema B. W. \& Van OfWegen L. P. 2004. - IndoMalayan ReefCorals: a Generic Overview. World Biodiversity database, CD-ROM Series ETI, Amsterdam.

Hoeksema B. W. \& KoH E. G. L. 2009. - Depauperation of the mushroom coral fauna (Fungiidae) of Singapore 
(1860s-2006) in changing reef conditions. Raffles Bulletin of Zoology, suppl. 22: 91-101.

Hoeksema B. W. \& GitTenberger A. 2010. - High densities of mushroom coral fragments at West Halmahera, Indonesia. Coral Reefs 29: 691.

Hoeksema B. W. \& Fransen C. H. J. M. 2011. - Space partitioning by symbiotic shrimp species cohabitating in the mushroom coral Heliofungia actiniformis at Semporna, eastern Sabah. Coral Reefs 30: 519.

Hoeksema B. W. \& Gittenberger A. 2011. - The position of Santo in relation to the centre of maximum marine biodiversity (the Coral Triangle) based on mushroom corals and their associated mollusc fauna, in Bouchet P., Le Guyader H. \& Pascal O. (eds), The Natural History of Santo. Patrimoines Naturels 70. Muséum national d'Histoire naturelle, Paris; IRD, Marseille; Pro-Natura International, Paris: 369-372.

HoeKsema B. W. \& MatTHews J. L. 2011. — Contrasting bleaching patterns in mushroom coral assemblages at Koh Tao, Gulf of Thailand. Coral Reefs 30: 95.

Hoeksema B. W. \& WAHEed Z. 2011. - Initial phase of autotomy in fragmenting Cycloseris corals at Semporna, eastern Sabah, Malaysia. Coral Reefs 30: 1087.

Hoeksema B. W. \& Yeemin T. 2011. - Late detachment conceals serial budding by the free-living coral Fungia fungites in the Inner Gulf of Thailand. Coral Reefs 30: 975.

Hoeksema B. W., Van der Land J., Van der Meij S. E. T., Van Ofwegen L. P., Reijnen B. T., Van Soest R. W. M. \& De Voogd N. J. 2011. - Unforeseen importance of historical collections as baselines to determine biotic change of coral reefs: the Saba Bank case. Marine Ecology 32: 135-141.

Hoeksema B. W., Van der Meij S. E. T. \& Fransen C. H. J. M. 2012. - The mushroom coral as a habitat. Journal of the Marine Biological Association of the United Kingdom 92: 647-663.

Laboute P. \& Richer DE Forges B. 2004. - Lagons et récifs de Nouvelle-Calédonie. Éditions Catherine Ledru, Nouméa, Nouvelle-Calédonie, 520 p.

Lane D. J. W. \& Rowe F. W. E. 2009. - A new species of Asterodiscides (Echinodermata, Asteroidea, Asterodiscididae) from the tropical southwest Pacific, and the biogeography of the genus revisited. Zoosystema 31 (3) : 419-429. http://dx.doi.org/10.5252/z2009n3a2

MCLEAN J. H. 2012. -New species and genera of colloniids from Indo-Pacific coral reefs, with the definition of a new subfamily Liotipomatinae n. subfam. (Turbinoidea, Colloniidae). Zoosystema 34 (2): 343-376. http://dx.doi.org/10.5252/z2012n2a10

MACPHERSON E. 2009. - New species of squat lobsters of the genera Munida and Raymunida (Crustacea,
Decapoda, Galatheidae) from Vanuatu and New Caledonia. Zoosystema 31 (3) : 431-451. http://dx.doi. org/10.5252/z2009n3a3

MACPHERSON E. 2012. - New deep-sea squat lobsters of the genus Galathea Fabricius, 1793 (Decapoda, Galatheidae) from Vanuatu and New Caledonia. Zoosystema 34 (2): 409-427. http://dx.doi.org/10.5252/z2012n2a13

Neusser T. P. \& Schrödl M. 2009. - Between Vanuatu tides: 3D anatomical reconstruction of a new brackish water acochlidian gastropod from Espiritu Santo. Zoosystema 31 (3) : 453-469. http://dx.doi. org/10.5252/z2009n3a4

PiCHON M. 2006. - Scleractinia of New Caledonia: check list of reef dwelling species, in PAYRI C. E. \& Richer DE Forges B. (eds), Compendium of Marine Species From New Caledonia. IRD, Nouméa: 147-155.

SÉRET B. \& LAST P. R. 2012. — New deep water skates of the genus Notoraja Ishiyama, 1958 (Rajoidei, Arhynchobatidae) from the southwest Pacific. Zoosystema 34 (2): 319-341. http://dx.doi.org/10.5252/z2012n2a9

Van Der Meij S. E. T., MoOlenbeek R. G. \& Hoeksema B. W. 2009. - Decline of the Jakarta Bay molluscan fauna linked to human impact. Marine Pollution Bulletin 59: 101-107.

Van der Meij S. E. T., Suharsono \& Hoeksema B. W. 2010. - Long-term changes in coral assemblages under natural and anthropogenic stress in Jakarta Bay (1920-2005). Marine Pollution Bulletin 60: 1442-1454.

VERON J. E. N. 1990a. - Checklist of the hermatypic corals of Vanuatu. Pacific Science 44: 51-70.

Veron J. E. N. 1990b. - Hermatypic corals, in Done T. \& Navin K. F. (eds), Vanuatu Marine Resources: Report of a Biological Survey. Australian Institute of Marine Science, Townsville: 37-65.

Veron J. E. N. 1990c. — New Scleractinia from Japan and other Indo-Pacific countries. Galaxea 9: 95-173. Veron J. E. N. 2000. — Corals of the World. Volume 2. Australian Institute of Marine Science, Townsville, 429 p.

Veron J. E. N., Devantier L. M., Turak E., Green A. L., Kininmonth S., Stafford-Smith M., Peterson N. 2009. - Delineating the Coral Triangle. Galaxea Journal of Coral Reef Studies 11: 91-100.

Veron J. E. N., Devantier L. M., Turak E., Green A. L., Kininmonth S., StafFord-Smith M., Peterson N. 2011. - The Coral Triangle, in DUBINSKY Z. \& Stambler N. (eds), Coral Reefs: an Ecosystem in Transition. Springer, Dordrecht: 47-55.

Weiner W. M., Bedos A. \& Deharveng L. 2009. Species of the genus Friesea (Collembola, Neanuridae) from New Caledonia and Vanuatu. Zoosystema 31 (3): 507-518. http://dx.doi.org/10.5252/z2009n3a8 